\title{
PENGARUH MEWARNAI GAMBAR TERHADAP TINGKAT KECEMASAN HOSPITALISASI PADA ANAK PRA SEKOLAH DI RS NURUL HASANAH KUTACANE TAHUN 2021
}

\author{
Yusnika Damayanti', Yessy Syahradesi², Evi Ernasari ${ }^{3}$ \\ ${ }^{1,2,3}$ STIKes Nurul Hasanah Kutacane \\ Email : yusnikadamayanti9@gmail.com
}

\begin{abstract}
The family has a health duty whose purpose is to prevent the occurrence of health problems and care for sick family members. There are five health tasks that must be done by the family dengan well. The implementation of this family health task is inseparable from the cultural factors owned by the family, such as the Minangkabau tribe who adhere to the patrilineal system. This research aims to identify the implementation of family health tasks in the Minangkabau tribe in Nogo Rejo Village of Galang Subdistrict. Research design is descriptive. Sampling with purposive sampling technique. A sample of 46 people consisted of 28 male respondents and 18 female respondents. The study was conducted from May 17 to July 12, 2021. Data collection is done using a questionnaire of family health tasks that includes demographic data and family health tasks. Then the data obtained is processed using descriptive analysis to determine the distribution of frequencies and percentages. The results showed that almost two-thirds (2/3) of respondents carried out family health duties in the Minangkabau tribe with a good category (63.04\%). The conclusion of this study shows that implementing family health duties in the Minangkabau tribe belongs to the category of $\operatorname{good}(63.04 \%)$.
\end{abstract}

Keywords: Family health, Minangkabau tribe, Hospitalization Anxiety

\section{PENDAHULUAN}

Hospitalisasi pada anak merupakan proses karena suatu alasan yang berencana atau darurat mengharuskan anak untuk tinggal di rumah sakit menjalani terapi dan perawatan sampai pemulangan kembali kerumah. Selama proses tersebut, anak dapat mengalami berbagai kejadian yang menunjukan pengalaman yang sangat trauma dan penuh dengan stress. Hospitalisasi merupakan salah satu penyebab stress baik pada anak maupun keluarganya, terutama disebabkan oleh perpisahan dengan keluarga, kehilangan kendali, perlukaan tubuh dan rasa nyeri. (Suparti, 2014)

Perasaan cemas merupakan dampak dari hospitalisasi yang dialami oleh anak karena menghadapi stressor yang ada dilingkungan rumah sakit. Pada umumnya reaksi anak terhadap sakit adalah kecemasan karena perpisahan, kehilangan, perlukaan tubuh, dan rasa nyeri. Perasaan tersebut dapat timbul karena menghadapi 
sesuatu yang baru dan belum pernah dialami sebelumnya. Pada masa prasekolah reaksi anak terhadap hospitalisasi adalah menolak makan, sering bertanya, menangis perlahan, tidak kooperatif terhadap petugas kesehatan. Sehingga perawatan di rumah sakit menjadi kehilangan kontrol dan pembatasan aktivitas. (Ramiah, 2003)

Berdasarkan hasil penelitian Nova, (2017) yang dilakukan di Rumah Sakit Nurul Hasanah Kutacane, tingkat kecemasan anak usia prasekolah sebelum intervensi sebesar $60 \%$ mengalami kecemasan berat, kecemasan sedang $30 \%$, dan kecemasan berat sekali $10 \%$. Setelah dilakukan terapi bermain, tingkat kecemasan anak yang mangalami kecemasan sedang sebanyak $50 \%$, kecemasan ringan $45 \%$, dan mengalami kecemasan berat sebanyak $5 \%$.

Hasil survey yang dilakukan peneliti di bagian Rekam Medik RS Nurul Hasanah Kutacane Tahun 2021, ditemukan jumlah pasien rawat inap pada anak pra sekolah tahun 2018 sebanyak 696 orang, dan pada bulan September 2019 sebanyak 172 orang, dengan jumlah pasien rawat inap perbulan sebanyak 58 orang.

Pada saat dirawat di rumah sakit, anak akan mengalami berbagai perasaan yang sangat tidak menyenangkan seperti cemas. Adapun tujuan bermain bagi anak di rumah sakit yaitu, mengurangi perasaan takut, cemas, sedih, tegang dan nyeri Anak usia pra sekolah mempunyai kemampuan motorik kasar dan halus yang lebih matang dari pada usia Toddler. Sejalan dengan pertumbuhan dan perkembangannya anak usia prasekolah sudah lebih aktif, kreatif dan imajinatif. (Santosa, 2019)

Permainan adalah satu dari aspek yang paling penting dalam kehidupan seorang anak, dan merupakan salah satu cara yang paling efektif untuk menghadapi dan mengatasi stress. Permainan adalah "pekerjaan" anak, dan dalam lingkup rumah sakit, permainan akan memberikan peluang untuk meningkatkan ekspresi emosional anak, termasuk pelepasan yang aman dari rasa marah dan benci. ((Hurlock, 2016)

Mewarnai gambar sebagai salah satu permainan yang memberikan kesempatan anak untuk bebas berekspresi dan sangat terapeutik (sebagai permainan penyembuh). Anak dapat mengekspresikan perasaannya dengan cara mewarnai gambar, ini berarti mewarnai gambar bagi anak merupakan suatu cara untuk berkomunikasi tanpa menggunakan kata-kata. (Suparti, 2014) 


\section{METODE}

Rancangan penelitian yang digunakan adalah quasy-eksperimental dengan rancangan nonequivalent control group design dimana dalam desain ini terdapat dua kelompok yaitu satu kelompok intervensi dan satu kelompok kontrol yang dipilih secara acak atau random kelompok intervensi dan kelompok kontrol. Dalam rancangan ini, kelompok intervensi adalah kelomok yang diberi perlakuan sedangkan kelompok kontrol tidak. Pada kedua kelompok perlakuan diawali dengan pra-tes, dan setelah pemeberian perlakuan diadakan pengukuran kembali (post-tes). (Budiarto, 2012)

Jenis penelitian quasyeksperimental yaitu untuk mengetahui pengaruh terapi bermain dengan mewarnai gambar terhadap penurunan kecemasan akibat hospitalisasi anak prasekolah di RS Nurul Hasanah Kutacane Tahun 2021.

Populasi pada penelitian ini adalah rata-rata jumlah anak pra sekolah yang rawat inap di RS Nurul Hasanah Kutacane pada setiap bulannya sebanyak 58 anak. Teknik pengambilan sampel dalam penelitian ini adalah accidental sampling yaitu pengambilan sampel pada saat penelitian dilakukan. Kriterian sampel yang digunakan adalah kriteria inklusi dimana kriteria yang diambil peneliti yaitu anak pra sekolah (3-5 tahun), anak yang sudah dirawat inap minimal 2 hari, permainan tidak bertentangan dengan pengobatan, orang tua memberi ijin untuk dilakukan penelitian pada anaknya.

\section{HASIL DAN PEMBAHASAN}

Tabel 1 Distribusi Frekuensi Responden Pre-test pada anak pra- sekolah di RS Nurul Hasanah Kutacane Tahun 2021.

\begin{tabular}{lcccccc}
\hline & \multicolumn{3}{c}{$\begin{array}{c}\text { Pre Test } \\
\text { Tingkat kecemasan }\end{array}$} \\
\cline { 2 - 7 } $\begin{array}{l}\text { Kelompok } \\
\text { Penelitian }\end{array}$ & \multicolumn{5}{c}{ Tidak } \\
& Cemas & \multicolumn{2}{c}{ cemas } \\
\cline { 2 - 7 } & $\mathbf{N}$ & $\mathbf{\%}$ & $\mathbf{N}$ & $\mathbf{\%}$ & $\mathbf{N}$ & \% \\
\hline $\begin{array}{l}\text { Kelompok } \\
\text { intervensi }\end{array}$ & 8 & 53,3 & 7 & 46,7 & 15 & 100 \\
\hline $\begin{array}{l}\text { Kelompok } \\
\text { kontrol }\end{array}$ & 9 & 60 & 6 & 40 & 15 & 100 \\
\hline
\end{tabular}

Berdasarkan Tabel 1 dapat diketahui bahwa tingkat kecemasan PreTest pada kelompok intervensi diperoleh $53,3 \%$ (8 Orang) tidak cemas dan 46,7\% (7 Orang) mengalami cemas, sedangkan tingkat kecemasan Pre- Test pada kelompok kontrol diperoleh $60 \%$ (9 Orang) tidak cemas dan $40 \%$ ( 6 orang) mengalami cemas.

Di ketahui bahwa semua anak pra sekolah yang hospitalisasi, selesai mewarnai ke 4 gambar yang sudah disediakan. Hasil gambar yang sudah diwarnai terlampir. Dengan demikian dapat di simpulkan bahwa bermain 
mewarnai gambar, merupakan salah satu teknik yang dapat digunakan untuk mengalihkan perasaan cemas, stres yang dialami anak selama menjalani masa perawatan/ sangat memiliki peran penting terhadap anak yang menjalani hospitalisasi.

Tabel 2 Distribusi frekuensi Post-test pada anak pra-sekolah di RS Nurul Hasanah Kutacane Tahun 2021.

\begin{tabular}{lllllll}
\hline & \multicolumn{4}{c}{ Post Test } & Total \\
Kelompok & \multicolumn{5}{c}{ Tingkat kecemasan } \\
\cline { 2 - 7 } Penelitian & Cemas & \multicolumn{2}{c}{ cemas } \\
& N & $\mathbf{\%}$ & $\mathbf{N}$ & $\mathbf{\%}$ & $\mathbf{N}$ & $\mathbf{\%}$ \\
\hline $\begin{array}{l}\text { Kelompok } \\
\text { intervensi }\end{array}$ & 0 & 0 & 15 & 100 & 15 & 100 \\
\hline $\begin{array}{l}\text { Kelompok } \\
\text { kontrol }\end{array}$ & 4 & 26,7 & 11 & 73,3 & 15 & 100 \\
\hline
\end{tabular}

Berdasarkan Tabel 2 dapat diketahui bahwa kecemasan anak Post test pada kelompok intervensi terdapat 15 orang tidak cemas, sementara pada kelompok kontrol terdapat 11 orang $(73,3 \%)$ tidak cemas dan 4 orang $(26,7 \%)$ cemas.

Berdasarkan hasil penelitian yang dilakukan di RS Nurul Hasanah Kutacane Tahun 2021, bahwa tingkat kecemasan anak pra sekolah yang mengalami hospitalisasi sebelum mewarnai gambar, terdapat 14 orang $(46,7 \%)$ tidak cemas, dan 16 orang $(53,3 \%)$ mengalami cemas.

Jika dibandingkan dengan hasil penelitian Rinikusuma 2018, tentang pengaruh mewarnai gambar terhadap tingkat kecemasan anak akibat hospitalisasi di Rumah Sakit Umum Daerah Soetomo Surabaya, sebelum diberikan intervensi, diperoleh jumlah anak yang mengalami kecemasan berat sebanyak 12 orang (60\%), kecemasan sedang sebanyak 6 orang $(30 \%)$, kecemasan berat sekali sebanyak 2 orang $(10 \%)$, tidak ada anak yang mengalami kecemasan ringan $0 \%$.

Asumsi peneliti berdasarkan hasil penelitian ini, bahwa tingkat kecemasan anak pra sekolah akibat hospitalisasi tergolong tinggi. Untuk itu di perlukan satu cara/ metode untuk menurunkan tingkat kecemasan anak yang sedang hospitalisasi.

Berdasarkan hasil penelitian yang dilakukan di Ruang Anak RS Nurul Hasanah Kutacane Tahun 2021, bahwa tingkat kecemasan anak pra-sekolah akibat Hospitalisasi sesudah mewarnai gambar, terdapat 26 orang $(86,7 \%)$ tidak cemas sedang dan 4 orang $(13,3 \%)$ mengalami cemas.

Jika dibandingkan dengan hasil Penelitian Rinikusuma 2018, jumlah anak prasekolah yang mengalami kecemasan 
sesudah intervensi diperoleh jumlah anak yang mengalami kecemasan sedang sebesar $50 \%$ sebanyak 20 orang, kecemasan ringan 9 orang $(45 \%)$, kecemasan berat 1 orang (5\%), dan tidak ada ditemukan anak yang tidak mengalami kecemasan dan anak yang mengalami kecemasan berat sekali.

Hasil penelitian ini sesuai dengan penelitian yang dilakukan (Eka, 2019) di Rumah Sakit Umum Daerah Yogyakarta, bahwa dengan mewarnai menggambar, anak dapat mengalihkan rasa cemas, stress dan jenuh selama menjalani Hospitalisasi. Dan Mewarnai lewat mewarnai gambar anak dapat ber-imajinasi, konsentrasi, sehingga dapat mengalihkan perhatiaan anak dan menurunkan tingkat kecemasan yang dialaminya.

Asumsi peneliti berdasarkan penelitian ini, bahwa terdapat perbedaan antara kelompok intervensi dengan kelompok kontrol, hasil penelitian ini menunjukkan bahwa mewarnai gambar merupakan salah satu media /cara yang dapat digunakan untuk menurunkan tingkat kecemasan Anak Pra Sekolah Akibat Hospitalisasi.

Berdasarkan Hasil penelitian yang dilakukan di Rumah Sakit Santa Pirngadi Medan Tahun 2021, diperoleh hasil analisa data dengan Uji Wilcoxon, nilai signifikancy $=0,002(\mathrm{p}<0,005)$, yang artinya Ho ditolak sehingga, terdapat perbedaan yang bermakna sebelum dan sesudah mewarnai gambar terhadap penurunan tingkat kecemasan hospitalisasi pada anak Pra Sekolah di RS Nurul Hasanah Kutacane Tahun 2021.

Jika dibandingkan dengan hasil penelitian yang dilakukan oleh (Eko, 2017) di Rumah Sakit Sukanto Yogyakarta tentang pengaruh mewarnai gambar terhadap tingkat kecemasan anak akibat hospitalisasi, diperoleh jumlah anak prasekolah yang mengalami kecemasan sedang sebelum dilakukan intervensi sebesar $52.63 \%$, namun setelah dilakukan intervensi kecemasan menurun menjadi kecemasan ringan sebesar $52.63 \%$.

Berdasarkan hasil penelitian ini, bahwa terdapat perbedaan kecemasan antara kelompok yang diberi perlakuan dengan kelompok kontrol. Dan, hasil penelitian ini menunjukkan bahwa mewarnai gambar merupakan salah satu media /cara yang dapat digunakan untuk menurunkan tingkat kecemasan Anak Pra Sekolah Akibat Hospitalisasi di RS Nurul Hasanah Kutacane Tahun 2021.

\section{KESIMPULAN DAN SARAN}

\section{Kesimpulan}

Tingkat tingkat kecemasan anak pra sekolah yang mengalami hospitalisasi sebelum terapi bermain mewarnai gambar, 
terdapat 14 orang $(46,7 \%)$ mengalami cemas sedang, dan 16 orang Tingkat kecemasan sesudah terapi bermain dengan mewarnai gambar, jumlah anak pra sekolah terdapat 26 orang $(86,7 \%)$ mengalami cemas sedang dan 4 orang $(13,3 \%)$ mengalami cemas berat. Berdasarkan hasil Analisa Data dengan Uji Wilcoxxon, terdapat hasil yang signifikan sebelum dan sesudah terapi mewarnai gambar, yaitu nilai signifikan $=0,002$ dimana $\mathrm{p}<0,005$, sehingga dengan demikian Ho ditolak, maka terdapat pengaruh mewarnai gambar terhadap penurunan tingkat kecemasan hospitalisasi pada anak prasekolah di RS Nurul Hasanah Kutacane Tahun 2021.

\section{Saran}

Hasil penelitian ini dapat dijadikan literatur di keperawatan anak dan menjadi tambahan informasi tentang pengaruh mewarnai gambar terhadap penurunan kecemasan hospitalisasi pada anak pra sekolah di RS Nurul Hasanah Kutacane Tahun 2021. Hasil penelitian ini dapat digunakan sebagai masukan bagi teman sejawat perawat, sebagai salah satu cara untuk menurunkan tingkat kecemasan anak pra sekolah akibat hospitalisasi dengan cara mewarnai gambar, namun untuk mencapai hasil yang maksimal di sarankan kepada Pihak RS Nurul Hasanah Kutacane Tahun 2021, untuk membuat 1 ruangan khusus sebagai tempat bermain buat anak Prasekolah yang sedang rawat inap.

\section{DAFTAR PUSTAKA}

Budiarto, E. (2012). Biostatistika Untuk Kedokteran dan Kesehatan Masyarakat. Jakarta: EGC.

Eka. (2019). Mengatasi Kecemasan pada Anak.

https://scholar.google.com/scholar?h $1=\mathrm{id} \&$

Eko. (2019). Pengaruh Terapi Bermain dengan Tekhnik Puzzle terhadap Penurunan Kecemasan Anak Prasekolah

https://scholar.google.com/scholar?h $1=\mathrm{id} \&$.

Hurlock, E. B. (2016). Developmental Psychology. Erlangga.

Nova, A. (2017). Implementasi konseling individu dan konseling kelompok untuk pembinaan akhlak siswa Madrasah Aliyah Islamic Centre Sumatera Utara. https://scholar.google.com/scholar?h $1=\mathrm{id} \&$

Ramiah, S. (2003). Kecemasan "bagaimana cara mengatasinya"Jakarta: Pustaka Popular Obor. 
Jurnal Maternitas Kebidanan, Vol 6, No. 2, Oktober 2021 ISSN 2599-1841

Santosa, Z. (2019). Mengenali Fraktur atau Keretakan. Jakarta: Alfa Media.

Suparti, Yupi. (2014). Konsep Dasar Keperawatan Anak. Jakarta: EGC. 